they are references of a layman as distinct from a trained ecologist-this is not necessarily a bad thing but can lead to a rather superficial view. The author seems to be weakest in describing the part played by the voluntary movement, which is at least as important as the Nature Conservancy, to which he devotes a whole chapter. It is in no way to decry the invaluable work done by the conservancy to say that limitation of its resources prevents it from doing more than half the job that needs to be done. The other half is being done by a host of volumteers, organized mainly in the county naturalists' trusts, but sometimes still working under the flag of an active local natural history society. A full assessment of the work of this side of the movement should find a place in one of the later editions of this book, which I hope the editors of the "New Naturalist" will be able to arrange. It is too useful a volume to be allowed to go out of date, as is inevitable with a fast developing move. ment such as we have in wildlife conservation in Britain.

R. S. R. FiTTER

\section{AIRBORNE INVASIONS}

\section{Migration and Dispersal of Insects by Flight}

By C. G. Johnson. Pp. xxii + 763. (Methuen: London, June 1969.) 150s.

THE author has been concerned with studies of insect migration at Rothamsted for more than 20 years. First, ho assisted Dr C. B. Williams, and then succeeded him as hcad of the entomology department. Many insect pests of agricultural or medical importance are migratory at some stage of their life history, so this scholarly and well planned volume will be particularly welcome to a wide range of practical entomologists; ecologists and physiologists interested in insccts will also find the book very stimulating.

The book consists of twenty-five chapters, grouped into six sections. General aspocts of migration are dealt within the first part, which includes a series of definitions and diagrams (most of which are easily understood) to distinguish the different types of migration. Physiological factors which initiate flight and cause individual insects to migrate are considored in part two. Detailed accounts of tho orientation of migrants in relation to topography and wind are well illustrated with diagrams and maps. The speeds of flight are listed rather inconsistently in nuiles per hour, metres or crm per sec in different tables. Physiological studies seem to set a limit of less than a day for continuous flight, yet there are recorded instances of very long range migrations over the sea which require the arriving migrants to have been continuously airborne for three days. Johnson wisely suggosts that as the numbers completing the journey are probably a minute fraction of the starters, these may either be exceptional physiologically or unusually fortunato in encountering a long succession of holpful upward air-currents.

The third part provides a valuable review of the studies of aerial plankton in relation to wcather; it would have been clearcr if it had been prefaced with a detailed account of the dynamics of the lower atmosphere in differont weathor conditions and had included a consideration of the likely time lags between tho initiation of flight and the arrival of insects at high altitudes. The author shows a sound and sceptical attitude to the cornmonly used multiple regression analyses of suction trap data, but he has missed the opportunity to discuss the figures in relation to what is known about those birds, like the swifts and the like, which rely on these migrating insects as a source of food. Tho diagram in Fig. 108 suggests some misunderstandings in the mind of the artist.

In parts four and five, short and long range migrations are considered in relation to insect life, history and synoptic meteorology. The desert locust, whose regular seasonal movements follow the intertropical convergence zone, provides a classical example of long range movement. An unusual deviation from the normal weather pattern in October 1954 brought some of these locusts from West Africa out over the Bay of Biscay up to the British Isles.

In part six, "Migration and Habitats", Johnson emphasizes the enormous numerical scale on which habitats are "bombarded", by aerial insects. Migrant insects attract notice only whon the species concernod aro spectacular and not normally present in the area of their arrival. In the British Isles, migrant butterflies and moths from Africa and southern Furope regularly appear and, as an exception, transatlantic species appear whon the winds are particularly favourable and achieve much publicity; but the inconspicuous migrant aphids which reach Britain in myriads each year on the casterly winds of spring are numerically and agriculturally far more important.

The ecologieal significance of migration is discussed in the final chapter and contrasted with flightlessness. Johnson rightly criticizes students of population dynamies who disregard migration and tend to under-rate its impact.

This is a well constructed book, written in a clear and vivid style, which enables the reader either to enjoy a logical account of insect migration on a world scale, or, with the aid of the good index and frequent cross-references in the text, to seek out what is known about some particular species of interest. The bibliography of over 1,200 entries lists publications from all over the world, but British and American papers predominate. About half of the references are to papers published since 1958, when the book by C. B. Williams on the same subject was published. Some of the references are to papers which appeared in 1969, so both the author and the publishers deserve congratulations for the speed with which the book has appeared and for its pleasing format and typographical accuracy.

G. C. VARLEY

\section{MATHS CREATED}

\section{Laws of Form}

By G. Spencer Brown. Pp. $\mathrm{xx}+142$. (Allen and Unwin: London, April 1969.) 45s.

ANYBODY who reviews books must subconsciously dread the situation I now face. It is new to me; nor do I expect to encounter it ever again. Intempcrate judgments may soon be proved wrong; but it is too casy to take a worldweary way out. Tho plain fact is that I suspect I am reviowing a work of genius. This is an extraordinary book. It is about mathematics. But this bold author devises his own mathematics from scratch, and makes few references to the history of that elegant discipline. True, there is reference (in an appendix) to somothing we knew about: Boolean algebra. Sheffer reduced Boole's whole logic to five umproven postulates. Spencer Brown proves all five in a casual couple of pages. As to the furnous "Sheffer stroke", itsclf a triurnph of mathematical simplification, Spencer Brown calmly says that "it may be omitted". He is right-as I now (but could not earlier) see. Nor would I previously have regarded Gödel's theorcm as logically trivial. These revised views are the result of spending two delightful days in St Mark's Square, immersed in this condensed and exquisitely poised argument.

Yes, the book is short. It virtually ends after sixtyeight pages with the conclusive words "and so on". There really does seem no more to be said. But the author allows us an equivalent ration of notes. Sample one of these: "Thus we cannot cscape the fact that the world wo know is constructed in order (and thus in such a way as to be able) to see itself. This is indeed amazing". To this I respond Amen-in several tones of voice. And all this begins by saying simply: "Draw a distinction". From there on, things just happen. We are introduced to an 